
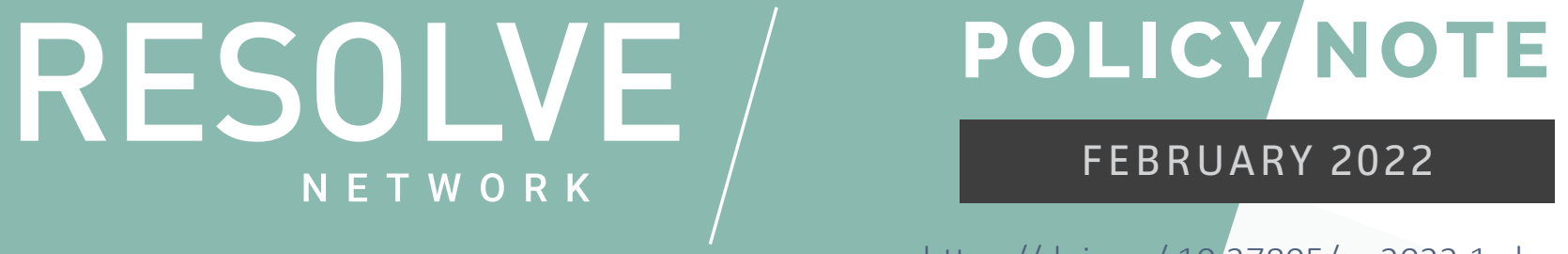

https://doi.org/ 10.37805/pn2022.1.cbags

\title{
GENDERED SECURITY SECTOR REFORM: WHAT CAN WE LEARN FROM WOMEN'S PARTICIPATION IN COMMUNITY-BASED ARMED GROUPS?
}

JAKANA THOMAS

COMMUNITY BASED ARMED GROUPS SERIES

\section{"Women's participation in CBAGs holds important implications for the national security of conflict-affected states.}

\section{FAST FACTS}

- That women have been active in local security can serve as a point of reference for states seeking to integrate more women into security institutions.

- For many African states pursuing gender integration in military institutions, public support has remained elusive.

- Key inhibitors of women's integration into armed forces are concerns about potential consequences for national security when militaries become gender diverse.

- While concerns that women will be abused, harassed and mistreated within military institutions are valid, greater scrutiny should be placed on those who engage in bad

behavior..

\section{Context}

West African women are frequently absent from discussions of community security, despite their substantial contributions to local defense. Women are often viewed primarily as beneficiaries of attempts to reduce local violence, such that their roles in community-based security are typically overlooked. Yet, West African women have long been on the front lines providing protection for their communities from internal and external threats. In 18th Century Whydah, now part of modern-day Benin, contingents of royal wives were tasked with interrupting conflicts between communities and enforcing the kingdom's laws. ${ }^{1}$ Dahomean women also served as royal palace guards and, more infamously, as feared warriors on the battlefield. A century later, Biafrian women participated in community-based militias to protect their communities during the Republic's war with

1 Stanley Alpern, Amazons of Black Sparta: The Women Warriors of Dahomey (New York: NYU Press, 2011). 
Nigeria. These trends are not anachronistic. Women have attained formal membership in many modern African community-based armed groups (CBAGs), including Nigeria's Civilian Joint Task Force (CJTF), Oodua People's Congress and Hisba militias, Sierra Leone's Civilian Defense Forces, as well as the Malian Ganda Koy and Patriotic Resistance Forces (FPR) coalition. CBAGs, which include security organizations as varied as hunter associations, vigilante groups, militias and gangs, engage in the important work of protecting their communities from everything from "petty crimes to insurgencies." 2

Though these forces are often portrayed as necessary vessels to defend vulnerable women and children, scarce attention is given to the women that join these organizations to protect their communities and themselves. Yet women's participation in CBAGs holds important implications for the national security of conflict-affected states. Understanding women's participation in community-based armed groups matters for successful demobilization, disarmament, and reintegration programs and for states' implementation of the global Women, Peace, and Security agenda, particularly gendered security sector reform. That women have been active-and in some cases instrumental - in establishing and maintaining local security can serve as a point of reference for states seeking to integrate more women into security institutions. States can use the gender dynamics of CBAGs as models to better understand the benefits and consequences of creating more gender-inclusive military institutions. Moreover, since CBAG politics are often governed by local norms and practices, understanding how women have become integrated into these local security structures can suggest means of achieving gendered security sector reform that are consistent with and respectful of local customs. This policy note briefly outlines and expounds upon some of the main insights of my recent study on women's participation in West African CBAGs. ${ }^{3}$ It proposes a set of considerations for states and stakeholders to structure efforts around gendered security sector reform.

\section{Relevance to policy and practice}

Women's increased involvement and integration into the security sector is an important way to improve women's security and well-being. In a recent digest, USAID proffered that "the security sector must include women and girls in decision-making roles in security institutions to ensure their services benefit women and girls as much as they benefit men and boys." ${ }^{4}$ Integrating women into security forces has been shown to decrease violence against civilians-especially women-support peacebuilding efforts, and shore-up civil-military relations. ${ }^{5}$ Therefore, a bedrock of successful security sector reform has been the integration of women into vital security

2 Daniel Agbiboa, Origins of Hybrid Governance and Armed Community Mobilization in Sub Saharan Africa, (Washington, D.C.: RESOLVE Network, 2019), https://doi.org/10.37805/cbags2019.2.

3 Jakana Thomas, Duty and Defiance: Women in Community Based Armed Groups in West Africa (Washington, D.C.: RESOLVE Network, 2021), https://doi.org/10.37805/cbags2021.1.

4 Chemonics International Inc., Gender and Security Sector Reform Toolkit (Washington, D.C.: United States Agency for International Development, 2021), https://www.usaid.gov/democracy/documents/gender-and-security-sector-reform-toolkit.

5 See, for example: Nina Wilén and Lindy Heinecken, "Regendering the South African Army: Inclusion, Reversal and Displacement," Gender Work Organization 25, no. 6 (2018): 670-686, https://doi.org/10.1111/gwao.12257; Sabrina Karim and Kyle Beardsley, Equal Opportunity Peacekeeping: Women, Peace, and Security in Post-Conflict States (Oxford: Oxford University Press, 2017). 
institutions.

African states have been at the forefront of embracing the global Women, Peace, and Security (WPS) agenda and the attendant calls for gendered security sector reform. At the end of 2019, 50 percent of the states in the African Union had already integrated parts of the WPS agenda into national action plans. Implementation of such plans has continued to prove challenging, however. ${ }^{6}$ Nigeria, for example, has attempted to make good on its commitments to the United Nations Security Council (UNSC) Resolution 1325 by integrating parts of the agenda into its domestic law. ${ }^{7}$ Despite progress, including the creation of its first Army Women's Corps in 2018, improvements have been inconsistent across its security sector with substantial heterogeneity across Nigerian states. ${ }^{8}$ To wit, fewer than half (14) of Nigeria's 36 states have implemented the country's National Action Plan (NAP) into domestic law. ${ }^{9}$ Benue State, for instance, has recently adopted a WPS Action Plan but still has far to go in getting "public buy-in on the importance of engaging women in decision-making" in the security sector. ${ }^{10}$

For many African states pursuing gender integration in military institutions, public support has remained elusive, in part due to persistent stereotypes alleging that women do not belong or will not thrive in the security realm. ${ }^{11}$ Bineta Diop, Senegal's Special Envoy to the African Union (AU) Commission on Women, Peace, and Security, has asserted that implementation is being stymied by "the patriarchal attitudes on the continent and the strong discrimination against women in the security world."12 Ultimately, these beliefs lead critics to conclude that security work is not appropriate for women, resulting in resistance to change when gendered security sector reform is attempted..$^{13}$

In South Africa, for example, even after the integration of a substantial number of female members in the armed forces, women are still confronted with the charge that they are not well-suited for security work. Despite a constitutional mandate and gender mainstreaming policy-which has helped propel female participation in the military to about 31 percent of the South African National Defence Force (SANDF), including 33 percent in leadership positions-sexual harassment, denigration, and an overall lack of consideration of their specific needs are still regular experiences for women in South Africa's military institutions. In an interview with a female Lieutenant, Adrian

6 Brigitte Hugh and Deekshita Ramanarayanan, "Africa in Transition: The Role of Women in Peace and Security," Wilson Center, October 2019, https://www.wilsoncenter.org/event/africa-transition-the-role-women-peace-and-security.

7 "Placing gender at the center of security sector reforms in Nigeria," UN Women: Africa, April 30, 2021, https://africa.unwomen. org/en/news-and-events/stories/2021/04/news---placing-gender-at-the-center-of-security-sector-reforms-in-nigeria.

8 Ibid.

9 Idris Ibrahim, "Nigeria Launches National Action Plan on Women, Peace, Security," Premium Times, May 10, 2017, https:// www.peacewomen.org/resource/nigeria-launches-national-action-plan-women-peace-security; "Women, Peace and Security Agenda Takes Centre Stage in Benue State, Nigeria," UN Women: Africa, July 1, 2021. https://africa.unwomen.org/en/ news-and-events/stories/2021/07/benue-state-sap-launch.

10 Ibid.

11 Salem Solomon, "African Women Surmount Obstacles to Redefine Their Countries' Militaries," Voice of America, February 24, 2019, https://www.voanews.com/a/african-women-surmount-obstacles-to-redefine-their-countries-militaries/4802120. html; Wilén and Heinecken, "Regendering the South African Army."

12 "APSACO 2021: Women, Peace and security in Africa Press Release," African Peace and Security Annual Conference, June 22, 2021, https://www.policycenter.ma/sites/default/files/SummaryAPSACO2021day1.pdf.

13 Fiona Pearce, "Why are So Few Women Deployed in UN Peacekeeping?," Australian Strategic Policy Institute, May 29, 2020, https://www.aspistrategist.org.au/why-are-so-few-women-deployed-in-un-peacekeeping/; Karim and Beardsley, Equal Opportunity Peacekeeping. 
Van Breda revealed that "the men feel as though women are inferior: only there to cook, clean and even expect sexual favours." A female Sergeant in South Africa's Air Force articulated that "most of [sic] women are harassed by senior ranks and don't want to come forward about it, because they're scared of their future." ${ }^{14}$ Even in leadership roles, women soldiers struggle to make male subordinates respect their authority. Men have also expressed incredulity about their female colleagues' emotional and physical capabilities, despite women persisting in the forces for decades and men facing similar challenges. ${ }^{15}$

Policymakers around the world have voiced concerns that their state's national security will be placed at risk when women are unprepared for security challenges they are likely to face on battlefields. ${ }^{16}$ They question whether adding women will imperil unit cohesion or distract their male comrades to disastrous effects ${ }^{17}$ and agonize about the prospect that female soldiers will be abused in the field. ${ }^{18}$ They also wonder whether their citizens are ready to embrace women in these untraditional roles. ${ }^{19}$ Some have suggested gender integration wait until gender norms and civilian attitudes become more receptive. ${ }^{20}$ These attitudes, as with all cultural and gender norms, are difficult to change and remediate, however. Without buy-in-or demands for greater inclusion of women-from the public, states have incentives to slow-walk the reform process. ${ }^{21}$ Yet, one way to generate greater acceptance of women's roles in security would be to demonstrate they would do well in security environments. An even better way to engender public support would be to show that women have already thrived in military institutions. Every day, women take on important security roles across the world, including in African states. This work continues to go unnoticed or ignored. ${ }^{22}$

Women make up significant proportions of the UN peacekeeping forces contributed by African states, including Ghana and Ethiopia. ${ }^{23}$ Women have also gained recognition for their oftenextensive roles in non-state armed groups by both policymakers and academics. ${ }^{24}$ They have

14 Adrian Van Breda, "Women Claiming Space in the Military: The Experiences of Female South African Soldiers," Journal of Human Ecology 53, no. 1 (2016): 25, https://doi.org/10.1080/09709274.2016.11906952.

For instance, motherhood is often invoked as a barrier to women's participation in the military, while fatherhood is not. Similarly, male soldiers frequently highlight women's fear in the field to disparage female participation, even in instances where male colleagues are also fearful and emotional. Wilén and Heinecken, "Regendering the South African Army."

16 Lindy Heinecken, "Conceptualizing the Tensions Evoked by Gender Integration in the Military: The South African Case," Armed Forces \& Society 43, no. 4 (2016): 202-220, https://doi.org/10.1177\%2F0095327X16670692.

17 Anna Simons, "Here's Why Women in Combat Units is a Bad Idea," War on the Rocks, November 18, 2014, https://warontherocks.com/2014/11/heres-why-women-in-combat-units-is-a-bad-idea/; "Women in Combat Pros and Cons," Sisters in Arms, n.d., https://sistersinarms.ca/history/women-in-combat-pros-and-cons/; Leeanne K. Simpson, "Eight myths about women on the military frontline - and why we shouldn't believe them," The Conversation, April 1, 2016, https://theconversation.com/eight-myths-about-women-on-the-military-frontline-and-why-we-shouldnt-believe-them-55594. Wilén and Heinecken, "Regendering the South African Army." Yomi Kazeem, "Nigeria's army has considered not admitting female combatants for training," Quartz Africa, November 14, 2017, https://qz.com/africa/1128815/nigeria-will-block-female-combat-soldiers-as-eritrea-ethiopia-algeria-boost-theirs/. "APSACO 2021: Women, Peace and security in Africa Press Release," African Peace and Security Annual Conference. "Deployment of Female Personnel Boosts Effectiveness, Says Secretary-General, as Security Council Holds Open Debate on Women in Peacekeeping," United Nations, April 11, 2019, https://www.un.org/press/en/2019/sc13773.doc.htm.

22 Thomas discusses several cases where significant numbers of West African women participated in CBAGs, yet women's participation was eventually erased or downplayed. Thomas, Duty and Defiance.

23 Pearce, "Why Are So Few Women Deployed."

24 Ibid. 
participated as supporters and combatants in rebel organizations and have long made contributions to community-based security organizations. ${ }^{25}$ Within these armed groups, women have worked alongside men, making important contributions to vital conflict processes. In states with hybridsecurity arrangements, where local defense is provided by local security actors, women's participation amounts to a proof of concept. Women's contributions are already essential for the provision of security in these highly insecure environments. Thus, arguments suggesting the implausibility of gendered security sector reform at the national-level have less merit.

\section{Key Considerations}

The following section provides insights and considerations for policymakers and practitioners when devising integrated efforts for gendered security sector reform.

\section{Leverage women's unique contributions}

Key inhibitors of women's integration into armed forces are concerns about potential consequences for national security when militaries become gender diverse. These reservations often reflect worst-case scenarios about what may go wrong when national security is vested in women's hands. While these concerns are foreboding, the lessons from CBAGs demonstrate the potential benefits for security organizations that effectively embrace gender diversity. ${ }^{26}$

There have been improvements in multiple domains when women were integrated into CBAGs. Women's participation in risky counterterrorism efforts has enhanced national security. Their integration into militias has led to decreased violence against civilians in internally displaced persons (IDP) camps and disruptions to terrorist activities. ${ }^{27}$ In Nigeria, militiawomen have been used to search and interrogate female suspects, which has preempted attacks by Boko Haram's would-be female suicide bombers. Nigerian female militia members have also leveraged their interpersonal connections to extract and share pertinent security information with militia and military members, which stymies violence by male militants as well. ${ }^{28}$

These are countering violent extremism (CVE) successes that can be attributed directly to women's formal involvement in CBAGs. They are also benefits that directly scale up from the community to the national level. Some of the dangerous missions and assignments female CBAG members have been tasked with are on par with the types of duties members of national armed forces and

25 Jakana L. Thomas and Kanisha D. Bond, "Women's Participation in Violent Political Organizations," American Political Science Review 109, no. 3 (2015): 3488-506, https://doi.org/10.1017/S0003055415000313; Reed M. Wood and Jakana L. Thomas, "Women on the Frontline: Rebel Group Ideology and Women's Participation in Violent Rebellion," Journal of Peace Research 54, no. 1 (2017): 31-46, https://doi.org/10.1177\%2F0022343316675025; Alexis Leanna Henshaw, Why Women Rebel: Understanding Women's Participation in Armed Rebel Groups (London: Routledge, 2016); “U.S. Strategy to Support Women and Girls at Risk from Violent Extremism and Conflict," U.S. Department of State, Office of Global Women's Issues, February 13, 2019, https://www.state.gov/u-s-strategy-to-support-women-and-girls-at-risk-from-violent-extremism-and-conflict/.

26 Thomas, Duty and Defiance.

27 Chitra Nagarajan, To Defend or Harm? Community Militias in Borno State, Nigeria (Center for Civilians in Conflict, 2020), https://civiliansinconflict.org/wp-content/uploads/2020/06/CommunityMilitiasFINAL_June2020lowres.pdf; Ene Osang,

"Zainab: Female CJTF That Protects Girls, Women From Rape," Global Sentinel, April 22, 2019.

Thomas, Duty and Defiance. 
international peacekeeping missions may face in conflict zones. As Fiona Pearce, gender advisor at the United Nations Department of Peace Operations, put it: "Women are as capable as men to perform military roles, and diversity in any organization makes that organization better." 29

Women have also used their informal connections with other women to deter young men's recruitment to Boko Haram and dissuade community members from supporting these violent actors. $^{30}$ The unique positioning of Nigeria's Igbo women and Mali's Tuareg women in their communities, informed by local gender norms, has enabled them to influence the uptake of violence or peace in their local areas. ${ }^{31}$ Women in security forces are also sometimes able to serve as bridges to the civilian population, which can improve civil-military relationships. ${ }^{32}$ Female peacekeepers in states as varied as Liberia, the Democratic Republic of Congo, Kosovo, and Afghanistan have in some instances been able to play a vital role where-unlike their male counterparts - they have been able to gain "access to 100 percent of the population, not 50 percent." ${ }^{33}$ Likewise, the UN Female Engagement Teams and U.S. Special Operations Cultural Support Teams (CSTs), have also been able to engage with parts of the population (e.g., women, children) that might be inaccessible to male soldiers. ${ }^{34}$ Improved relationships with the local population are essential for information gathering, trust-building, dispersal of conflict, and the implementation of early warning systems, all important ingredients for successful peacekeeping. ${ }^{35}$ In addition to increasing access to hard-to-reach populations, studies have also shown that women are able to form greater interpersonal connections with other women and are viewed as more trustworthy than men in similar positions. ${ }^{36}$ These attributes can facilitate high-level peace negotiations, local peacebuilding efforts, and operational or tactical counterinsurgency missions.

Women also provide stability for peace processes and stop abhorrent behavior by armed actors, including state and local forces. ${ }^{37}$ The reduction of civilian victimization when women are integrated into military forces has been noted with respect to UN peacekeeping forces by both practitioners

29 Pearce, "Why Are So Few Women Deployed."

30 Orji Sunday, "Hajiya Hamsatu Allamin is One of the Most Powerful Conflict Mediators with Boko Haram, So Why Won't Anyone Listen?" The Establishment, September 13, 2018, https://medium.com/the-establishment/hajiya-hamsatu-allamin-is-one-of-the-most-powerful-conflict-mediators-with-boko-haram-so-why-wont-2a4927a39f26; Orji Sunday, "The Brave Women Fighting Boko Haram in Nigeria," Al Jazeera, July 10, 2019, https://www.aljazeera.com/news/2019/7/10/ the-brave-women-fighting-boko-haram-in-nigeria.

31 Thomas, Duty and Defiance; Hilary Matfess, Brokers of Legitimacy: Women in Community-Based Armed Groups (Washington DC: RESOLVE Network, 2020). https://doi.org/10.37805/cbags2020.1.

32 Wilén and Heinecken, "Regendering the South African Army."

33 Alexandra Ivanovic, "Why the United Nations Needs More Female Peacekeepers," United Nations University, July 9, 2014, https://unu.edu/publications/articles/why-un-needs-more-female-peacekeepers.html.

34 Terri Moon Cronk, "Cultural Support Team Women Serve with Distinction," U.S. Army, April 30, 2015, https://www.army. mil/article/147493/cultural_support_team_women_serve_with_distinction; Ivanovic, "Why the United Nations Needs More Female Peacekeepers."

35 Ibid.

36 Linda Babcock and Sara Laschever, Women Don't Ask: Negotiation and the Gender Divide (Princeton, NJ: Princeton University Press, 2003); Tamra Pearson d'Estree and Eileen F. Babbitt. "Women and the Art of Peacemaking: Data from IsraeliPalestinian Interactive Problem-Solving Workshops," Political Psychology 19, no. 1 (1998): 185-209, https://www.jstor.org/ stable/3792121.

37 Solomon, "African Women Surmount Obstacles to Redefine Their Countries' Militaries." 
and academics. ${ }^{38}$ Reporting of sexual and gender-based incidents also increases when women are more prevalent among peacekeeping contingents. ${ }^{39}$ Similarly, in Nigeria, Female CJTF members have reported that their presence and vigilance has led to a reduction in sexual exploitation and abuse by military officers in IDP camps. ${ }^{40}$ Thousands more women in the Vigilante Group of Nigeria (VGN) have been trained to detect and report abuse against women and children, such as sexual violence and trafficking. ${ }^{41}$ Recognizing these potential benefits of women's inclusion, military forces should concentrate their attention on providing support, training, incentives, and encouragement for female soldiers to protect other women. It is vital, however, to be cautious about overstating the responsibility for-and ability of-women to prevent abuses against civilians. Men in the military, armed groups, and the general population must also be held accountable for their actions. ${ }^{42}$ Efforts that change attitudes and set consequences for bad behavior must be a part of the process of security sector reform. ${ }^{43}$

Even in states reluctant to allow women to participate in overt combat or in roles considered "men's work," women's unique positions can be leveraged by engagement teams. Further, states should not allow arguments about women's fitness to hold them back from allowing women to be integrated in the military. In instances where women have participated in conflicts willingly, they have demonstrated their ability to operate efficiently and effectively under pressure. ${ }^{44}$ Most important, however, is that in conflict zones, women's lives are already at great risk regardless of their overt participation in conflict. Thus, restricting female participation in the military over fears women will be harmed in conflict ${ }^{45}$ overlooks the everyday dangers women endure and manage in conflict-affected states, while simultaneously preventing them from being a part of the solution. ${ }^{46}$

\section{Recognize women's contributions to replicate lessons learned}

Despite women's substantial contributions to the initiation, maintenance, and termination of conflicts, their participation has been frequently ignored, overlooked, and diminished. ${ }^{47}$ Governments, local political figures, and armed groups have denied women's involvement and centrality to local security activities. For instance, even though the Kamajor militia drafted female recruits at a crucial point during the civil war in Sierra Leone, they not only denied that women were ever among their ranks but also prohibited female members from taking part in the

38 Karim and Beardsley, Equal Opportunity Peacekeeping; "Deployment of Female Personnel Boosts Effectiveness," United Nations.

39 "Deployment of Female Personnel Boosts Effectiveness," United Nations.

40 Osang, "Zainab: Female CJTF That Protects Girls."

41 Hussein Yahaya, "Vigilantes Empower Members Against Rape," Daily Trust, April 3, 2017, https://allafrica.com/stories/201704030209.html.

42 For example, see: Christopher Isike, "Change What South African Men Think of Women to Combat their Violent Behaviour," The Conversation, October 4, 2021, https://theconversation.com/change-what-south-african-men-think-of-women-to-combat-their-violent-behaviour-167921.

43 Ernest Hersh, "Security reform key to protecting women," Africa Renewal, 2012, https://www.un.org/africarenewal/ magazine/special-edition-women-2012/security-reform-key-protecting-women.

44 Thomas, Duty and Defiance.

45 Heinecken, "Conceptualizing the Tensions Evoked by Gender Integration in the Military."

46 Women often join violent political organizations to protect themselves and other women within their communities from sexual and gender-based violence. Thomas, Duty and Defiance.

47 Ibid. 
demobilization process. ${ }^{48}$ Tuareg and Biafran women's contributions to security provision were similarly downplayed, even though in both cases their involvement was vital for the execution and sustenance of their communities' war efforts. ${ }^{49}$

Failing to recognize women's contributions to security not only renders the work women have done invisible, it also makes it difficult to replicate any success attributed to women's participation. If women make specific, meaningful contributions to security at the community and national levels, but those contributions are overlooked or denied, they cannot be leveraged in the future. By downplaying women's historical activities, especially as it relates to counterterrorism, counterinsurgency, and peacebuilding, practitioners who hope to learn lessons that can be transposed onto other contexts will miss key ingredients responsible for success. Moreover, if women do not receive recognition contemporaneously for their contributions, they are unlikely to be credited later, which could convince well-meaning actors there is little merit to investing in women's integration into CBAGs or military institutions. On the other hand, by acknowledging what women do on the frontlines and behind the scenes, political actors may have a greater impetus to prioritize women's inclusion in the future. Also, seeing women thrive in these positions may empower other women to pursue new opportunities in security, which may help boost female recruitment in cases where too few eligible women seek out these roles. ${ }^{50}$

\section{Include women in DDR programs}

Gendered demobilization, disarmament, and reintegration (DDR) is an essential pillar of the Women, Peace, and Security agenda. UNSC 1325 implores all stakeholders to consider gendered perspectives, including female ex-combatants' unique needs, when designing and implementing DDR programs in conflict-zones. This provision recognizes that peace and stability cannot be achieved, if women are systematically excluded from the benefits of DDR. To this end, it is important to consider the range of violent actors that need to be demobilized and reintegrated after a conflict. While rebel women's exclusion from DDR programs has garnered significant attention recently, DDR programs' omission of women from pro-government, self-defense, and civil defense forces has evaded the spotlight. Yet, concerns about gender equity in DDR are also likely to exist among

48 Megan MacKenzie, Female Soldiers in Sierra Leone: Sex, Security, and Post-conflict Development (New York: NYU Press, 2015), 8.

49 Thomas, Duty and Defiance; Egodi Uchendu, Women and Conflict in the Nigerian Civil War (Trenton, NJ: Africa World Press, 2007), 121; Zoe Gorman and Grégory Chauzal, "Hand in Hand': A Study of Insecurity and Gender in Mali," SIPRI, 2019, https://www.sipri.org/publications/2019/sipri-insights-peace-and-security/hand-hand-study-insecurity-and-gender-mali. Although it is alleged that Tuareg women have little involvement with conflict, they do offer support to the fighters and have unique power to sanction conflict in their homes or communities.

50 Women are more likely to seek out combat roles in militaries when they observe other women joining as well. See, for example: Douglas Yeung, Christina E. Steiner, Chaitra M. Hardison, Lawrence M. Hanser, and Kristy N. Kamarck, "Recruiting Policies and Practices for Women in the Military Views from the Field," RAND, 2017. https://www.rand.org/content/dam/rand/pubs/research_reports/RR1500/RR1538/RAND_RR1538.pdf; Jena McGregor, "Getting More Women into Army Leadership," The Washington Post, June 3, 2014, https://www.washingtonpost.com/news/on-leadership/ wp/2014/06/03/getting-more-women-into-army-leadership/; "Military Women Discuss Taboos and Stigmas They Face in UN Peace Operations," International Peace Institute, October 20, 2020, https://www.ipinst.org/2020/10/ woman-first-soldier-second-taboos-and-stigmas-facing-military-women-in-un-peace-operations\#2. 
militias and have similarly dire consequences if left ignored.

A sizeable challenge of demobilizing women within rebel groups has been gleaning which women constitute legitimate combatants and which are attempting to gain benefits they are not entitled to. While gaining access to DDR programs is problematic for some male combatants as well, women-as a group - are often excluded from participating in DDR programs, while this is never the case for men. In other words, while DDR equity is a problem for both men and women, these programs are often biased against women as a group, while only unfair to some specific men. Those overseeing DDR programs are hesitant to assume that "all women or girl ex-combatants should be considered soldiers; a hesitation that does not exist with respect to male ex-combatants, even though some men and boys also fill support rather than combat roles." ${ }^{51}$ Armed groups and DDR programs often adopt terms that distinguish women's participation (i.e., women associated with armed forces/groups, war wives) from men's, even when women take on active and risky roles in conflicts. $^{52}$

The 22,000 women that signed up for Liberia's demobilization process were registered as "women associated with the fighting forces" (WAFF), despite more than two-thirds of these women selfidentifying as combat soldiers. ${ }^{53}$ A similar distinction was not made of male soldiers. Moreover, although the program was supported by a peace process with a clear gender perspective and a mandate to take the needs of women seriously, women were incorporated into the program at a far lesser rate than their actual participation in the conflict. ${ }^{54}$ Amnesty International suggests this discrepancy may have resulted from the program being led by a group of men who believed women should not be involved in the DDR process, poor information disseminated specifically to women, commanders' gender discrimination, and the stigma of being branded a WAFF. ${ }^{55}$ Women's activities were similarly vital to the Mozambican, Sierra Leonean, and Indonesian civil conflicts, but women were largely overlooked as candidates for demobilization in these conflicts, even where compensation was afforded to civilian women. ${ }^{56}$

Determining whether women qualify for DDR programs is likely to be similarly difficult when it pertains to community-based armed groups. This is because CBAGs, particularly those raised by conservative communities, often downplay women's contributions, even when significant and indispensable. These militias tend to recruit women reluctantly and only when their needs are great, which makes them less keen to admit how central or important women were to their efforts. Some groups go so far as to deny that any women ever participated, even when clear evi-

51 Kathleen Jennings, "The Political Economy of DDR in Liberia: A Gendered Critique," Conflict, Security \& Development 9, no. 4 (2009): 475-494, https://doi.org/10.1080/14678800903345770; See also: Chris Coulter, Mariam Persson, and Mats Utas, Young Female Fighters in African Wars: Conflict and Its Consequences (Stockholm: Nordic Africa Institute, Uppsala, 2008), http://nai.diva-portal.org/smash/get/diva2:241304/FULLTEXT01.

52 Amnesty International, Liberia: A flawed process discriminates against women and girls, March 31, 2008, https://www. amnesty.org/en/wp-content/uploads/2021/07/afr340042008eng.pdf.

53 Jennings, "The Political Economy of DDR in Liberia," 482.

54 Amnesty International, Liberia: A flawed process.

55 Ibid.

56 Wenche Iren Hauge, "Gender Dimensions of DDR - Beyond Victimization and Dehumanization: Tracking the Thematic," International Feminist Journal of Politics 22, no. 2 (2019): 206-226, https://doi.org/10.1080/14616742.2019.1673669. 
dence confirms the contrary. ${ }^{57}$ In more traditional or conservative communities, arguments about women's place in security drives this sleight-of-hand. But these denials do more than undercut women's achievements; they also make it difficult to justify including women in DDR processes, which creates incentives for women to seek alternative means of recouping the material benefits they lose out on when they are excluded from DDR.

In the past, DDR programs have promoted the idea that reintegrating male combatants into society is a more important goal, since only idle men are believed to threaten stability. ${ }^{58}$ However, research on civil conflict makes clear that most individuals join armed groups to gain and maintain material benefits, and the importance of these selective incentives as a recruitment tool appears to be consistent across genders. ${ }^{59}$ In Cote d'Ivoire, for example, some women and men that initially joined pro-government militias switched to the rebel side when the expected costs and benefits of supporting a given side changed. Likewise, male and female former rebels joined militias when pro-government activism appeared more beneficial. ${ }^{60}$ This supports arguments that conflict actors can be swayed by pecuniary incentives during conflicts. Thus, if only men are enticed away from violence by promises of the rewards they will receive during demobilization, women have few incentives to turn away from violence and return to society. Moreover, women in armed groups often face higher barriers in assimilating back into society after conflicts, given societal attitudes about women's involvement in violence. ${ }^{61}$ Thus, it may be easier for women to return to violence than to their communities when they lack the tools and support that DDR programs can offer.

\section{Practical Recommendations}

In summary, from a practical standpoint, to achieve long-term peace and stability, robust DDR programs must acknowledge and accommodate the full range of conflict actors. Three practical recommendations follow.

1. DDR programs should have specific provisions for militias, groups that are often left out of DDR and related peace processes, despite strong incentives and ability to continue fighting. ${ }^{62}$ This is consequential, since research shows that when militias act as counterinsurgents, conflicts are significantly more likely to recur. ${ }^{63}$

2. Policymakers and practitioners that oversee the implementation of DDR programs should be skeptical of pronouncements like those in Mali, Sierra Leone, and Nigeria that women

57 Thomas, Duty and Defiance.

58 Jennings discusses that in Liberia providing for male employment and re-entry into the workforce is more important than women's, as only unemployed men would pose a threat to peace. With women, they are only concerned about prostitution. Jennings, "The Political Economy of DDR in Liberia."

59 Thomas, Duty and Defiance.

60 Ibid.

61 Alexis Leanna Henshaw, "Female Combatants in Postconflict Processes: Understanding the Roots of Exclusion." Journal of Global Security Studies 5, no. 1 (2020): 63-79, https://doi.org/10.1093/jogss/ogz050.

62 Christoph Steinert, Janina I. Steinert, and Sabine C. Carey, "Spoilers of peace: Pro-government militias as risk factors for conflict recurrence," Journal of Peace Research 56, no. 2 (2019): 249-263, https://doi.org/10.1177\%2F0022343318800524.

63 Steinert, Steinert, and Carey, "Spoilers of peace." 
writ large are absent from a war effort. Program officers should recognize the broad array of contributions that women make to armed groups, including those in militias, and should avoid minimizing or trivializing the types of participation women more frequently engage in. To ensure that more women have access to DDR benefits, practitioners, funders, and stakeholders should avoid making distinctions between women fighters and women supporters, ensure that DDR applications of male and female recruits are similarly scrutinized, and understand how male commanders' biases uniquely disenfranchise women applicants to DDR programs. ${ }^{64}$

3. Policymakers should not prioritize men's participation in DDR over women's based solely on assumptions that men's buy-in is more essential to peace and stability. Both men and women's participation contribute to war, so both men and women should be offered the same incentives to make the transition to peace attractive and feasible.

\section{Conclusion}

The many examples provided in this report indicate that even when female fighters have been integral to armed groups' success, they have been excluded disproportionately from post-conflict benefits, including participation in their states' post-conflict militaries. ${ }^{65}$ Conflict experiences, however, have been sufficient to qualify men for recruitment into post-conflict armed forces. ${ }^{66}$ Therefore, after demonstrating their ability to engage in security work in armed groups and militias, there are few justifiable reasons for women to be barred from state militaries writ large.

If states, including those with ambitious WPS state action plans, hope to move forward with gendered security sector reform, there are familiar models they can reference that could guide this process. In particular, non-state armed groups, including community-based militias, have already leveraged West African women's participation successfully. States can look to these experiences for a better understanding of the consequences or benefits of gender diversity.

While concerns that women will be abused, harassed and mistreated within military institutions are valid, greater scrutiny should be placed on those who engage in bad behavior, rather than potential victims of abuse. Moreover, it is important to remember that civilian women are not safe

64 As in the case of Liberia, women are often left out of DDR processes when commanders provide false information about women's participation to DDR officials, intentionally misinform women about whether they are qualified for demobilization, and confiscate women's weapons for their own personal monetary gain. Thousands of UNIMIL applicants incorrectly received benefits, often at the expense of women and girls who should have qualified. See, for example: Dyan Mazurana, Roxanne Krystalli, and Anton Baaré, "Gender and Disarmament, Demobilization, and Reintegration: Reviewing and Advancing the Field," in The Oxford Handbook of Gender and Conflict, eds. Fionnuala Ní Aoláin, Naomi Cahn, Dina Francesca Haynes, and Nahla Valji (Oxford: Oxford University Press, 2018), https://doi.org/10.1093/oxfordhb/9780199300983.013.35; Amnesty International, Liberia: A flawed process.

65 Mazurana, Krystalli, and Baaré, "Gender and Disarmament, Demobilization, and Reintegration"; Amnesty International, Liberia: A flawed process. For example, female soldiers were excluded from Eritrea's and South Sudan's militaries, despite substantial contributions to rebels' wartime armies.

Steinert, Steinert, and Carey, "Spoilers of peace." 
from abuse in war zones, as the recent crisis in Ethiopia's Tigray region demonstrates. ${ }^{67}$ Preliminary evidence suggests, however, that sexual exploitation and abuse decrease when militaries integrate women, and even more progress can be made when institutions prioritize gender equality. ${ }^{68}$

67 Civilian women endure many types of violence during conflicts, including increased rape, sexual exploitation and abuse, and intimate partner violence. Jocelyn T. D. Kelly, Elizabeth Colantuoni, Courtland Robinson, and Michele R. Decker, "Quantifying the Ripple Effects of Civil War: How Armed Conflict Is Associated with More Severe Violence in the Home," Health Human Rights 23 no. 1 (2021): 75-89, https://www.hhrjournal.org/2021/06/ quantifying-the-ripple-effects-of-civil-war-how-armed-conflict-is-associated-with-more-severe-violence-in-the-home/.

68 Sabrina Karim and Kyle Beardsley, "Explaining Sexual Exploitation and Abuse in Peacekeeping Missions: The Role of Female Peacekeepers and Gender Equality in Contributing Countries," Journal of Peace Research 53, no. 1 (2016): 100-115, https:// doi.org/10.1177\%2F0022343315615506. 


\section{Suggested Further Reading}

\section{On Community Based-Armed Groups}

Agbiboa, Daniel. Origins of Hybrid Governance and Armed Community Mobilization in Sub Saharan Africa. Washington, D.C.: RESOLVE Network, 2019. https://doi.org/10.37805/cbags2019.2.

Van Metre, Lauren. From Self-Defense to Vigilantism: A Typology Framework of Community-Based Armed Groups. Washington, D.C.: RESOLVE Network, 2019. https://doi.org/10.37805/cbags2019.3.

\section{On Gender Politics of CBAGs}

Matfess, Hilary. Brokers of Legitimacy: Women in Community-Based Armed Groups. Washington, D.C.: RESOLVE Network, 2020. https://doi. org/10.37805/cbags2020.1.

Thomas, Jakana. Duty and Defiance: Women in Community-based Armed Groups in West Africa. Washington, D.C.: RESOLVE Network, 2021. https:// doi.org/10.37805/cbags2021.1.

\section{On Gender and Security Sector Reform}

Bastick, Megan, and Tobie Whitman. A Women's Guide to Security Sector Reform. Washington, D.C.: The Institute for Inclusive Security and Geneva Centre for the Democratic Control of Armed Forces, 2013. https://www.inclusivesecurity.org/wp-content/uploads/2015/09/WGTSSR-Web.pdf.

Chemonics International Inc. Gender and Security Sector Reform Toolkit. Washington, D.C.: United States Agency for International Development, 2021. https://www.usaid.gov/democracy/documents/gender-and-security-sector-reform-toolkit.

\section{On Women in DDR}

Hills, Christopher, and Megan MacKenzie. "Women in Non-State Armed Groups after War: The (Non) Evolution of Disarmament, Demobilization and Reintegration." In The Palgrave International Handbook of Gender and the Military, edited by Rachel Woodward and Claire Duncanson, 455471. London: Palgrave MacMillan, 2017. https://link.springer.com/chapter/10.1057/978-1-137-51677-0_28.

Mazurana, Dyan, Roxanne Krystalli, and Anton Baaré. "Gender and Disarmament, Demobilization, and Reintegration: Reviewing and Advancing the Field." In The Oxford Handbook of Gender and Conflict, edited by Fionnuala Ní Aoláin, Naomi Cahn, Dina Francesca Haynes, and Nahla Valji, Oxford: Oxford University Press, 2018. https://doi.org/10.1093/oxfordhb/9780199300983.013.35.

Vastapuu, Leena. "Not Enough Soldier, Not Enough Civilian: The Continuing Under-Representation of Female Soldiers in Disarmament, Demobilisation, and Reintegration (DDR) Programmes." In Routledge Handbook of Feminist Peace Research, edited by Tarja Väyrynen, Swati Parashar, Élise Féron, and Catia Cecilia Confortini, 231-239. London: Routledge, 2021. https://doi.org/10.4324/9780429024160-25. 


\section{Bibliography}

"APSACO 2021: Women, Peace and security in Africa Press Release." African Peace and Security Annual Conference. June 22, 2021. https://www. policycenter.ma/sites/default/files/SummaryAPSACO2021day1.pdf.

"Deployment of Female Personnel Boosts Effectiveness, Says Secretary-General, as Security Council Holds Open Debate on Women in Peacekeeping." United Nations, April 11, 2019. https://www.un.org/press/en/2019/sc13773.doc.htm.

"Military Women Discuss Taboos and Stigmas They Face in UN Peace Operations." International Peace Institute, October 20, 2020. https://www. ipinst.org/2020/10/woman-first-soldier-second-taboos-and-stigmas-facing-military-women-in-un-peace-operations\#2.

"Placing gender at the center of security sector reforms in Nigeria." UN Women: Africa, April 30, 2021. https://africa.unwomen.org/en/ news-and-events/stories/2021/04/news---placing-gender-at-the-center-of-security-sector-reforms-in-nigeria.

"U.S. Strategy to Support Women and Girls at Risk from Violent Extremism and Conflict." U.S. Department of State, Office of Global Women's Issues, February 13, 2019. https://www.state.gov/u-s-strategy-to-support-women-and-girls-at-risk-from-violent-extremism-and-conflict/.

"Women in Combat Pros and Cons." Sisters in Arms, n.d. https://sistersinarms.ca/history/women-in-combat-pros-and-cons/.

"Women, Peace and Security Agenda Takes Centre Stage in Benue State, Nigeria." UN Women: Africa, July 1, 2021. https://africa.unwomen.org/en/ news-and-events/stories/2021/07/benue-state-sap-launch.

Agbiboa, Daniel. Origins of Hybrid Governance and Armed Community Mobilization in Sub-Saharan Africa. Washington, D.C.: RESOLVE Network, 2019. https://doi.org/10.37805/cbags2019.2.

Alpern, Stanley. Amazons of Black Sparta: The Women Warriors of Dahomey. New York: NYU Press, 2011.

Amnesty International. Liberia: A flawed process discriminates against women and girls. March 31, 2008. https://www.amnesty.org/en/wp-content/ uploads/2021/07/afr340042008eng.pdf.

Babcock, Linda, and Sara Laschever. Women Don't Ask: Negotiation and the Gender Divide. Princeton, NJ: Princeton University Press, 2003.

Chemonics International Inc. Gender and Security Sector Reform Toolkit. Washington, D.C.: United States Agency for International Development, 2021. https://www.usaid.gov/democracy/documents/gender-and-security-sector-reform-toolkit.

Coulter, Chris, Mariam Persson, and Mats Utas, Young Female Fighters in African Wars: Conflict and Its Consequences. Stockholm: Nordic Africa Institute, Uppsala, 2008. http://nai.diva-portal.org/smash/get/diva2:241304/FULLTEXT01.

Cronk, Terri Moon. "Cultural Support Team Women Serve with Distinction." U.S. Army, April 30, 2015. https://www.army.mil/article/147493/ cultural_support_team_women_serve_with_distinction;

Gorman, Zoe, and Grégory Chauzal. "'Hand in Hand': A Study of Insecurity and Gender in Mali." SIPRI, 2019. https://www.sipri.org/publications/2019/ sipri-insights-peace-and-security/hand-hand-study-insecurity-and-gender-mali.

Hauge, Wenche Iren. "Gender Dimensions of DDR - Beyond Victimization and Dehumanization: Tracking the Thematic." International Feminist Journal of Politics 22, no. 2 (2019): 206-226. https://doi.org/10.1080/14616742.2019.1673669.

Heinecken, Lindy. "Conceptualizing the Tensions Evoked by Gender Integration in the Military: The South African Case." Armed Forces \& Society 43 no. 4 (2016): 202-220. https://doi.org/10.1177\%2F0095327X16670692.

Henshaw, Alexis Leanna. "Female Combatants in Postconflict Processes: Understanding the Roots of Exclusion." Journal of Global Security Studies 5, no. 1 (2020): 63-79. https://doi.org/10.1093/jogss/ogz050.

Henshaw, Alexis Leanna. Why Women Rebel: Understanding Women's Participation in Armed Rebel Groups. London: Routledge, 2016.

Hersh, Ernest. "Security reform key to protecting women." Africa Renewal, 2012. https://www.un.org/africarenewal/magazine/ special-edition-women-2012/security-reform-key-protecting-women.

ReSOlVe Policy Note \Gendered Security Sector Reform | 14 
Hugh, Brigitte, and Deekshita Ramanarayanan. "Africa in Transition: The Role of Women in Peace and Security." Wilson Center, October 2019. https://www.wilsoncenter.org/event/africa-transition-the-role-women-peace-and-security.

Ibrahim, Idris. "Nigeria Launches National Action Plan on Women, Peace, Security." Premium Times, May 10, 2017. https://www.peacewomen.org/ resource/nigeria-launches-national-action-plan-women-peace-security.

Isike, Christopher. "Change What South African Men Think of Women to Combat their Violent Behaviour." The Conversation, October 4, 2021. https://theconversation.com/change-what-south-african-men-think-of-women-to-combat-their-violent-behaviour-167921.

Ivanovic, Alexandra. "Why the United Nations Needs More Female Peacekeepers." United Nations University, July 9, 2014. https://unu.edu/publications/articles/why-un-needs-more-female-peacekeepers.html.

Jennings, Kathleen. "The Political Economy of DDR in Liberia: A Gendered Critique." Conflict, Security \& Development 9, no. 4 (2009): $475-494$. https://doi.org/10.1080/14678800903345770.

Karim, Sabrina and Kyle Beardsley. Equal Opportunity Peacekeeping: Women, Peace, and Security in Post-Conflict States. Oxford: Oxford University Press, 2017.

Karim, Sabrina, and Kyle Beardsley. "Explaining Sexual Exploitation and Abuse in Peacekeeping Missions: The Role of Female Peacekeepers and Gender Equality in Contributing Countries." Journal of Peace Research 53, no. 1 (2016): 100-115. https://doi.org/10.1177\%2F0022343315615506.

Kazeem, Yomi. “Nigeria's army has considered not admitting female combatants for training." Quartz Africa, November 14, 2017. https://qz.com/ africa/1128815/nigeria-will-block-female-combat-soldiers-as-eritrea-ethiopia-algeria-boost-theirs/.

Kelly, Jocelyn T. D., Elizabeth Colantuoni, Courtland Robinson, and Michele R. Decker. "Quantifying the Ripple Effects of Civil War: How Armed Conflict Is Associated with More Severe Violence in the Home." Health Human Rights 23, no. 1 (2021): 75-89. https://www.hhrjournal.org/2021/06/ quantifying-the-ripple-effects-of-civil-war-how-armed-conflict-is-associated-with-more-severe-violence-in-the-home/.

MacKenzie, Megan. Female Soldiers in Sierra Leone: Sex, Security, and Post-conflict Development. New York: NYU Press, 2015.

Matfess, Hilary, Brokers of Legitimacy: Women in Community-Based Armed Groups. Washington, D.C.: RESOLVE Network, 2020. https://doi. org/10.37805/cbags2020.1

Mazurana, Dyan, Roxanne Krystalli, and Anton Baaré. "Gender and Disarmament, Demobilization, and Reintegration: Reviewing and Advancing the Field." In The Oxford Handbook of Gender and Conflict, edited by Fionnuala Ní Aoláin, Naomi Cahn, Dina Francesca Haynes, and Nahla Valji, Oxford: Oxford University Press, 2018. https://doi.org/10.1093/oxfordhb/9780199300983.013.35.

McGregor, Jena. "Getting More Women into Army Leadership." The Washington Post, June 3, 2014. https://www.washingtonpost.com/news/ on-leadership/wp/2014/06/03/getting-more-women-into-army-leadership/.

Nagarajan, Chitra. To Defend or Harm? Community Militias in Borno State, Nigeria. Center for Civilians in Conflict, 2020. https://civiliansinconflict. org/wp-content/uploads/2020/06/CommunityMilitiasFINAL_June2020lowres.pdf.

Pearce, Fiona. "Why are So Few Women Deployed in UN Peacekeeping?." Australian Strategic Policy Institute, May 29, 2020. https://www.aspistrategist.org.au/why-are-so-few-women-deployed-in-un-peacekeeping/.

Pearson d'Estree, Tamra, and Eileen F. Babbitt. "Women and the Art of Peacemaking: Data from Israeli-Palestinian Interactive Problem-Solving Workshops." Political Psychology 19, no. 1 (1998): 185-209. https://www.jstor.org/stable/3792121.

Simons, Anna. "Here's Why Women in Combat Units is a Bad Idea." War on the Rocks, November 18, 2014. https://warontherocks.com/2014/11/ heres-why-women-in-combat-units-is-a-bad-idea/.

Simpson, Leeanne K. "Eight myths about women on the military frontline - and why we shouldn't believe them." The Conversation, April 1, 2016. https://theconversation.com/eight-myths-about-women-on-the-military-frontline-and-why-we-shouldnt-believe-them-55594.

Solomon, Salem. "African Women Surmount Obstacles to Redefine Their Countries' Militaries." Voice of America, February 24, 2019. https://www. voanews.com/a/african-women-surmount-obstacles-to-redefine-their-countries-militaries/4802120.html. 
Steinert, Christoph, Janina I. Steinert, and Sabine C. Carey. "Spoilers of peace: Pro-government Militias as Risk Factors for Conflict Recurrence." Journal of Peace Research 56, no. 2 (2019): 249-263. https://doi.org/10.1177\%2F0022343318800524.

Sunday, Orji. "Hajiya Hamsatu Allamin is One of the Most Powerful Conflict Mediators with Boko Haram, So Why Won't Anyone Listen?.” The Establishment, September 13, 2018. https://medium.com/the-establishment/hajiya-hamsatu-allamin-is-one-of-the-most-powerful-conflictmediators-with-boko-haram-so-why-wont-2a4927a39f26.

Sunday, Orji. "The Brave Women Fighting Boko Haram in Nigeria." Al Jazeera, July 10, 2019. https://www.aljazeera.com/news/2019/7/10/ the-brave-women-fighting-boko-haram-in-nigeria.

Thomas, Jakana L., and Kanisha D. Bond. "Women's Participation in Violent Political Organizations." American Political Science Review 109, no. 3 (2015): 3488-506. https://doi.org/10.1017/S0003055415000313.

Thomas, Jakana. Duty and Defiance: Women in Community-based Armed Groups in West Africa. Washington, D.C.: RESOLVE Network, 2021. https:// doi.org/10.37805/cbags2021.1.

Uchendu, Egodi. Women and Conflict in the Nigerian Civil War. Trenton, NJ: Africa World Press, 2007.

Van Breda, Adrian. "Women Claiming Space in the Military: The Experiences of Female South African Soldiers." Journal of Human Ecology 53 no. 1 (2016): 20-28. https://doi.org/10.1080/09709274.2016.11906952.

Wilén, Nina, and Lindy Heinecken. "Regendering the South African Army: Inclusion, Reversal and Displacement," Gender Work Organization, 25 no. 6 92018): 670-686. https://doi.org/10.1111/gwao.12257.

Wood, Reed M., and Jakana L. Thomas. "Women on the Frontline: Rebel Group Ideology and Women’s Participation in Violent Rebellion." Journal of Peace Research 54, no. 1 (2017): 31-46. https://doi.org/10.1177\%2F0022343316675025.

Yahaya, Hussein. “Vigilantes Empower Members Against Rape.” Daily Trust, April 3, 2017. https://allafrica.com/stories/201704030209.html.

Yeung, Douglas, Christina E. Steiner, Chaitra M. Hardison, Lawrence M. Hanser, and Kristy N. Kamarck. "Recruiting Policies and Practices for Women in the Military Views from the Field" RAND, 2017. https://www.rand.org/content/dam/rand/pubs/research_reports/RR1500/RR1538/RAND_ RR1538.pdf. 


\section{About the Note}

\section{Author: Jakana Thomas}

Jakana Thomas is Associate Professor in the School of Global Policy and Strategy at the University of California, San Diego. She is an expert on political violence with an emphasis on the behavior of violent non-state actors. Her research examines women's participation in rebel, terrorist and community-based violent organizations and the determinants of successful peace processes. She is associate editor of the H-DIPLO/International Security Studies Forum and a member of the RESOLVE Research Advisory Council.

The views expressed in this publication are those of the authors. They do not necessarily reflect the views of the RESOLVE Network, the U.S. Institute of Peace, or any entity of the U.S. government.

\section{RESOLVE NETWORK}

better research.informed practice.improved policy on violent extremism. 